\title{
Discovery of \\ Tumor Suppressor Gene Function
}

\author{
Steven B. Oppenheimer
}

W

E get many cancers because our tumor suppressor genes, which can prevent cancer, become damaged or destroyed. In 1991 I presented a review on tumor suppressor genes in this journal (Oppenheimer 1991). At that time, however, nobody knew how these genes worked. Understanding how they work should lead to therapies that may finally offer cures for advanced cancers. This update of the 1991 article was written because the major breakthrough in an understanding of the function of tumor suppressor genes has just occurred.

It is believed that damage to the p53 tumor suppressor gene is responsible for up to $50 \%$ of all human cancers (Marx 1993). An understanding of how this gene prevents cancer and how damage to it causes cancer surely would be considered to be one of the most important developments in cancer research of all time.

In the last few weeks this breakthrough has taken place. The work by Wade Harper, Stephen Elledge, Bert Vogelstein and colleagues has shown that the p53 tumor suppressor gene codes for protein that acts to turn on genes that code for other proteins that can suppress cell division (Harper et al. 1993; El-Deiry et al. 1993). Curt Harris of the National Cancer Institute described this finding as "pretty spectacular" (Marx 1993).

Enzymes known as cyclin-dependent kinases (Cdks) become associated with proteins called cyclins. Together, they bring cells through the cell cycle and cell division. The $\mathrm{p} 53$ gene makes a protein that turns on the gene for a 21 kilodalton protein. This 21 $\mathrm{kD}$ protein complexes with the cyclin-dependent kinase/cyclin units in normal cells, preventing DNA synthesis and cell division (Figure 1) (Harper et al. 1993; El-Deiry et al. 1993).

What is especially exciting about this finding is that the $21 \mathrm{KD}$ protein just described blocks cell division and appears to be increasingly expressed in aging cells (Marx 1993). The gene for this protein has

Steven B. Oppenheimer, Ph.D., is Director of the Center for Cancer and Developmental Biology, and Trustees Outstanding Professor at California State University, Northridge, 18111 Nordhoff St., Northridge, CA 91330-8303. become a good candidate for explaining how senescent cells lose their ability to divide. A key to aging as well as cancer now may be in hand (Marx 1993).

The dream of slowing down the aging process and successfully treating advanced cancer may well become a reality in the not-too-distant future. Drugs based on the $21 \mathrm{KD}$ protein may be developed that could slow down cell division in cancer cells, or speed it up, perhaps negating some of the characteristics of the aging process.

The final part of this brief review deals with the discovery of a human colon cancer gene and how it functions. One in every 200 people possess a defective gene that causes up to $15 \%$ of all colon cancers. This defective gene was discovered by Fishel's group at the University of Vermont and Kinzler and Vogelstein's group at Johns Hopkins University (Fishel et al. 1993; Marx 1993). In the normal state this gene codes for a protein that functions in the repair of DNA. Obviously, anything that causes improperly repaired DNA could result in many cellular defects, including cancer (Figure 2).

The defective gene called HNPCC, for hereditary nonpolypoisis colon cancer, was mapped on chromosome 2. All patients with this form of colon cancer were found to possess the defective gene (Fishel et al. 1993; Marx 1993). A final piece to the puzzle fit into place when it was found that DNA repair was indeed defective in colon cancer cells and that the DNA of these cells was 100 times more easily mutated than that of normal cells (Marx 1993).

The identification and chromosomal localization of the HNPCC gene is making the possibility of mass public screening for this gene a reality. Since colon cancer is very curable if found early, screening for this gene, followed by careful monitoring of those who possess it, promises to substantially decrease mortality from one of the most common human cancers.

Advances in molecular biology are making their way into the diagnosis and treatment of diseases. There is great optimism that advances such as those described here will lead to the conquest of diseases that so far have escaped medicine's not-so-mighty sword. 


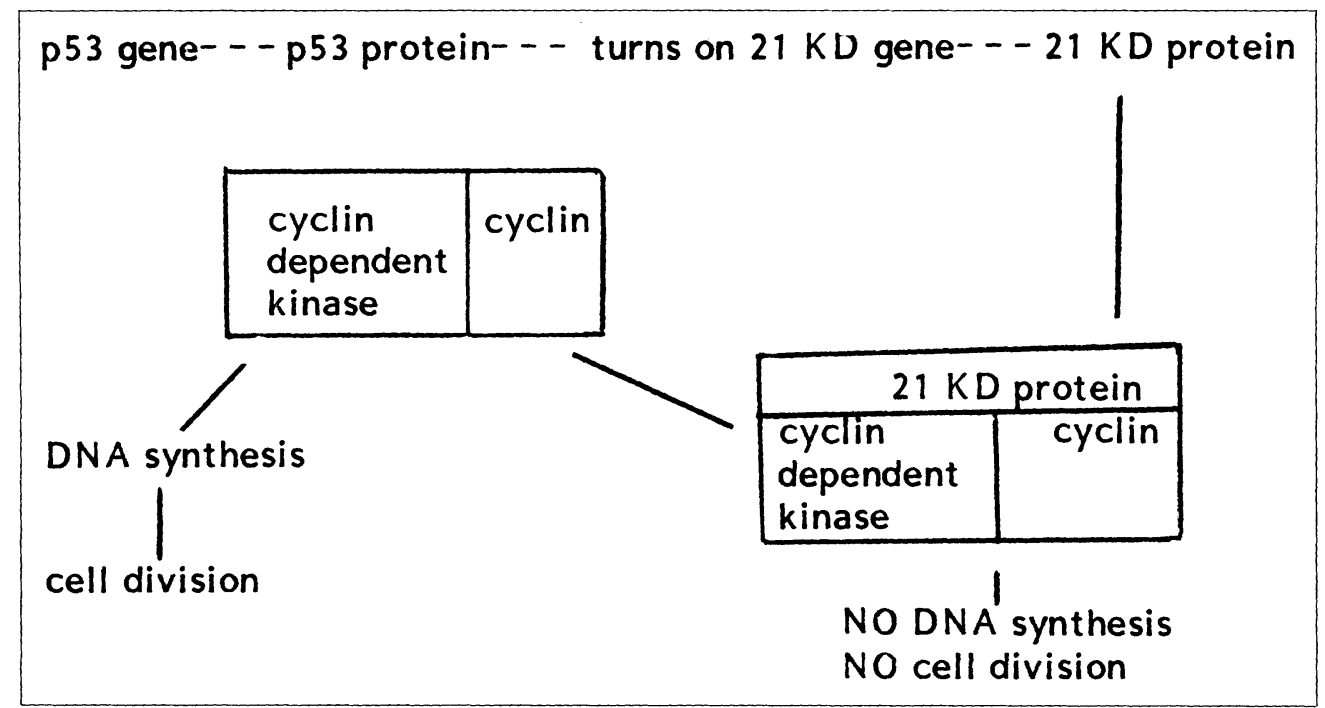

Figure 1. Function of the p53 tumor suppressor gene. The p53 gene codes for a protein that turns on another gene coding for a $21 \mathrm{KD}$ protein. This protein combines with the cyclin-dependent kinase/cyclin complex, blocking DNA synthesis and cell division that would be caused by this complex in the absence of the $21 \mathrm{KD}$ protein.

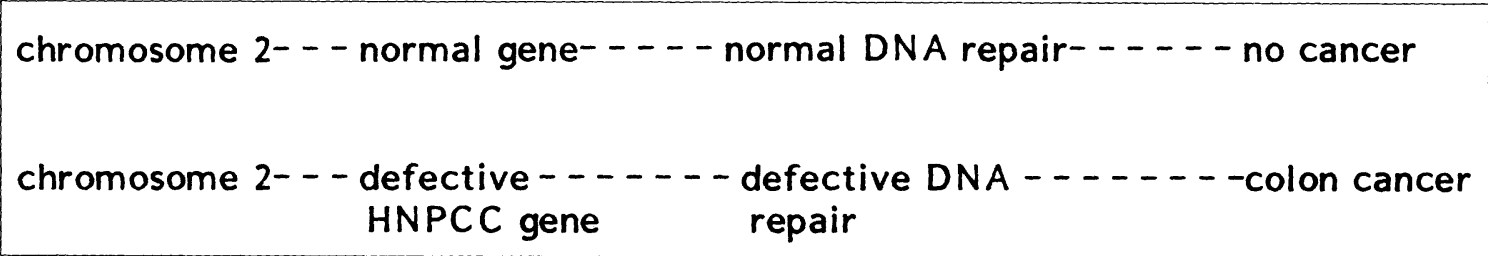

Figure 2. Identification and function of human colon cancer gene. A normal gene on chromosome 2 codes for a protein that functions in the proper repair of damaged DNA. The defective HNPCC gene results in defective DNA repair that can lead to colon cancer.

Bringing the latest advances in biology to our students is one way to interest them in pursuing careers in research science. Another is to involve them directly in hands-on research projects. We have used both of these approaches for more than two decades in my research lab supported by NIH, NSF, NASA, the Joseph Drown Foundation and Thomas Eckstrom Trust, and in teacher enhancement programs supported by NSF, UCSP, and the Eisenhower and Howard Hughes Medical Institutes. If you would like a free copy of our several-hundred-page, NSFsponsored handbook to help you develop a research program using these approaches in your school, just write the author. This is the first article of two brief reviews that bring the hottest new advances in biology to your classroom. This advance in the discovery of tumor suppressor gene function, along with the article on the discovery of noggin to be published in May $A B T$, were selected from hundreds of develop- ments in recent months, as among the most exciting advances in biology of all time.

\section{References}

$\rightarrow$ El-Deiry, W.S. et al. (1993). WAF1, a potential mediator of p53 tumor suppression. Cell, 75, 817-825.

$\rightarrow$ Fishel, R. et al. (1993). The human mutator gene homolog MSH2 and its association with hereditary nonpolypoisis colon cancer. Cell, 75, 1027-1038.

$\rightarrow$ Harper, J.W. et al. (1993). The p21 CDK-interacting protein Cip 1 is a potent inhibitor of G1 cyclindependent kinases. Cell, 75, 805-816.

$\rightarrow$ Marx, J. (1993). How p53 suppresses cell growth; gene defect identified in common hereditary colon cancer. Science, 262, 1644-1645.

$\rightarrow$ Oppenheimer, S.B. (1991). Tumor suppressor genes: A key to the cancer puzzle? The American Biology Teacher, 53(1), 22-24. 